\title{
DETERMINANT FOR POSITIVE OPERATORS AND OPPENHEIM'S INEQUALITY
}

\author{
SORA HiRAMATSU AND YUKI SEO
}

Abstract. In this paper, by virtue of the Specht ratio, we show Oppenheim type inequalities for the normalized determinant of positive invertible operators on a Hilbert space, and we moreover discuss Hadamard type inequalities for positive definite matrices.

Mathematics subject classification (2020): Primary 47A63; Secondary 15A45. operator

Keywords and phrases: Hadamard product, determinant, Oppenheim inequality, positive invertible

\section{REFERENCES}

[1] W. B. ARVeson, Analyticity in operator algebras, Amer. J. Math., 89 (1997), 578-642.

[2] B. Fuglede AND R. V. KADISON, On determinants and a property of the trace in finite factors, Proc. Nat. Acad. Sci. U.S.A. 36 (1951), 425-431.

[3] B. Fuglede and R. V. Kadison, Determinant theory in finite factors, Ann. Math., 55 (1952), $520-530$.

[4] J. I. FuJII, The Marcus-Khan theorem for Hilbert space operators, Math. Japon., 41 (1995), 531-535.

[5] J. I. FujII, S. IZUMino AND Y. SEO, Determinant for positive operators and Specht's Theorem, Sci. Math., 1 (1998), 307-310.

[6] J. I. Fujil AND Y. SEO, Determinant for positive operators, Sci. Math., 1 (1998), 153-156.

[7] M. FujiI, J. Mićić Hot, J. PeČArić And Y. SeO, Recent Developments of Mond-Pečarić Method in Operator Inequalities, Monographs in Inequalities 4, Element, Zagreb, 2012.

[8] I. PAulsen, Completely Bounded Maps and Dilations, Pitman Res. Notes Math., 146, 1986.

[9] Y. SEO, A generalized Pólya-Szegö inequality for the Hadamard product, Sci. Math. Japon., 72 (2010), $165-169$.

[10] W. Specht, Zur Theorie der elementaren Mittel, Math. Z., 74, (1960), 91-98.

[11] F. Zhang, Matrix Theory - Basic Results and Techniques, Second edition, Universitext, Springer, 2011. 